EXPERIÊNCIAS SÔRRE A UTILIDADE DA PANELA DE PRES SĀO COMO AUTOCLAVE

Yoriko Kamiyama*

INTRODUÇÃO

Em 1964, na Escola de Enfermagem da Universi dade de São Paulo, a equipe de Fundamentos de Enfermagem, dis cutindo a possibilidade de se obter um método prático e eficiente de esterilização no domicílio, levantou a hipótese da possibilidade da utilizaçāo da panela de pressão como autoclave.

Consultada a bibliografia específica foram encon tradas as seguintes citaçōes:

"A panela de pressão doméstica, que nos é tão familiar, é uma pequena autoclave". (6)

"Autoclave é um dos tipos evolutivos da marmita de Papin, ou panela de pressāo".

Na bibliografia disponível não se encontrou des crição de experiências que demonstrassem o modo prático de estê rilizar com a utilização da panela de pressão doméstica. Foi com ésse objetivo em mente que, no ano acima citado, iniciamos nos sos primeiros estudos com a colaboração de Esther Moraes e Zü leika Courrol, na época instrutora de Fundamentos de Enferma gem e estudante do 19 ano de graduação, respectivamente, no le vantamento inicial de dados para o planejamento do estudo propos to. A ambas deixamos aqui consignado o merecido crédito.

Nāo se duvida, atualmente, do enorme benefício trazido ao contrôle das infecçōes microbianas pela descoberta de meios potentes de esterilização. Dos métodos existentes de este rilização o mais eficiente é o da autoclave. No entanto, a eficiên

* Prof́essôra Assistente do Departamento de Enfermagem MédicoCirúrgica da Escola de Enfermagem da Universidade de Sáo Pau 10. 
cia do procedimento esterilizador por autoclave fica limitada, des de logo, pelo custo elevado da instalação e manutenção dêsse equi pamento. Por essa limitação inicial o uso de autoclave a domicí lio é proibitivo. Nem mesmo é empregado êste aparelho de modo geral, em farmácias, consultórios médicos ou dentários, centros e postos de saúde.

Nestas pequenas instituiçōes de saúde, bem co mo no domicílio, geralmente são utilizados os agentes químicos e principalmente a água em ebulição, deixando-se o material expos to ao calor durante 5 a 15 minutos. Êstes procedimentos são de restrita eficiência.

E ainda relativamente grande, entre nós, a inci dência de infecçōes pós-injeçāo (infecçōes piogênicas e hepatite por virus B), supuração de ferimentos cujo curativo foi feito com material contaminado, infecçōes intestinais pelo uso de mamadei ras contaminadas, etc...

O objetivo dêste trabalho é demonstrar a possibi lidade da utilização da panela de pressão como autoclave e estabé lecer o processo a ser adotado para ésse fim.

Pretendemos, assim, poder proporcionar um re curso para a esterilização, prático, eficiente e acessível à popula çāo em geral, bem como às pequenas instituiçōes de saúde.

\section{CONSIDERAÇŌES GERAIS}

Nāo nos ueteremos em consideraçōes detalhadas no que diz respeito à esterilização em autoclave, em virtude da abundante literatura existente; destacaremos apenas alguns as pectos essenciais para fundamentar éste trabalho.

\section{Esterilizaçāo em autoclave}

$$
\text { "Autoclave é um aparelho baseado no mesmo }
$$
princípio da marmita de Papin, a saber, que a água aquecida em recipiente fechado, onde o vapor fica retido sob pressāo, pode atin gir temperaturas muito elevadas sem ferver". (1) 
Reconhecida a existência do mundo microbiano e a influência dos microorganismos nas infecçōes e na fermentação e putrefaçāo da matéria, foram iniciados os estudos para a desco berta de meios de contrôle daqueles agentes biológicos.

Inicialmente foi comprovada a eficiência da água em ebuliçāo para destruir os germes na forma vegetativa, verifi cando-se também que os esporulados, na sua maioria, resistiam à temperatura de $1009 \mathrm{C}$.

Na procura de um método mais eficiente, Char les Chamberland, em 1880, desenvolveu o da esterilização em aú toclave.

Entre os inúmeros procedimentos de esteriliza ção que foram descobertos e que vêm sendo utilizados, o método da autoclave tem provado ser o mais eficiente de todos. Cousiste, resumidamente, na esterilizaçāo por meio do vapor dágua sob pressão. Neste, a temperatura é o elemento fundamental e a pressāo o elemento necessário para a vaporização do líquido à temperatura desejada. Existe, pois, relação precisa entre a tem peratura e a pressão na autoclave.

Entre os fatôres que influem na autoclavagem. cabe-nos aqui considerar apenas a condição básica para que a es terilização seja eficiente, isto é, que o vapor atinja tôdas as par tes do material. Para isso deve-se utilizar apenas $85 \%$ da capaci dade da autoclave e o material deve ser preparado e colocado de modo a possibilitar a penetração do vapor em tôdas as regiōes a esterilizax.

Normalmente, o material de superfície é esteri lizado à temperatura de $1219 \mathrm{C}-15 \mathrm{lb} / \mathrm{pol}^{2}$ de pressão, em $15 \mathrm{mi}$ nutoe $\mathrm{e}$ o de densidade em 30 minutos*.

* Material de superfície - E aquêle em que o vapor entra em con $£$ tacto sòmente com a superfície do material.

Material de densidade - E aquêle em que o vapor entra em con tacto com cada fibra do material e com tódas as camadas do mes mo. 
Há vários modêlos de autoclave. O mais utiliza do em algumas das pequenas instituiçōes de saúde e nos laborató rios de Bacteriologia é o vertical, aquecido a gás. A panela de pressão se assemelha a êste tipo de autoclave.

Resistência dos microorganismos ao calor

Os microorganismos apresentam grande variaki lidade em sua capacidade de resistência ao calor. Em geral, a.s formas vegetativas são menos resistentes que as esporularas, seiz do destruídas a $1009 \mathrm{C}$, em 30 minutos. O vírus $\mathrm{B}$ da hepatite e a maioria dos esporulados sòmente sāo destruídos a 121 ㅇ C en 13 minutos.

Até o presente não há uma explicação satĭsfat ria para a grande termo-resistência dos esporos. Parece ser de vida ao baixo teor de água e principalmente ao estado insolívei em que se encontram suas proteínas.

O quadro 1 mostra o tempo específico para destruição pelo calor úmido, determinado por vários autores, de esporos microbianos.

\section{Quadro n? 1}

TEMPO ESPEC IFICO PARA DESTRUIÇĀO, PELO CALOR IJM! DO. DE ESPOROS MICROBIANOS.

\begin{tabular}{l|c|c|c|c|c|l|}
\hline \multirow{2}{*}{ MICROORGANISMO } & \multicolumn{7}{|c|}{ Temperatura em graus C. } & \multirow{2}{*}{ AUTORES } \\
\cline { 2 - 6 } & 100 & 105 & 110 & 115 & $120-121$ & \\
\hline \hline B. anthracis & $5-10$ & - & - & - & - & Stein Rogers \\
B. subtilis & $6-17$ & - & - & - & - & Schneiter Kolb \\
Cl. botulinem & 300 & 100 & 32 & 10 & 4 & Esty Meyca \\
Cl. tetani & $5-15$ & $5-10$ & - & - & - & Murray Headlee \\
Cl. Welchii & $5-10$ & - & - & - & - & Headlee \\
Thermophiles & 834 & 405 & 100 & 40 & $11-12$ & Bigelow
\end{tabular}


Testes de eficiência da autoclave

Há diversos tipos de testes de eficiência sendo o melhor dêles o biológico, em que se usam, como contrôle, cadar ços contaminados com esporos do Bacillus subtilis.

Êsse teste deve ser realizado da seguinte mane: ra: semear o bácilo em meio sólido, de preferência no meio dé Sabouraud; incubar na estufa a 37\%C, durante 48 horas ou mais: até se conseguir acentuada esporulação; preparar, a seguir, uma suspensão dessa cultura com soluçāo fisiológica esterilizada; cor: taminar os cadarços de contrôle nesta suspensāo; proceder à pro. va de contaminação com um dêsses cadarços, colocando-o em ce: do glicosado ou no meio de Thioglicolato; incubar na estuía 2 37\%C. O crescimento dos bácilos após 24 horas confirmará = contaminação dos cadarços de contrôle. A seguir, colocar os cá. darços no interior de um pequeno campo, fazer o pacote e colocar no centro da autoclave entre os demais. Ligar o aparelho e envi ar o cadarço de contrôle ao laboratório após a autoclavagers.

\section{APRESENTAÇĀO E ANÅLISE DAS EXPERIÊNCIAS}

O trabalho constou das seguintes fases: verifica ção da temperatura e pressāo alcançadas pelas panelas de pre: são; determinação do processo a ser adotado para a esterilizá çāo na panela de pressāo; testes de eficiência da esteriilizaçäo na panela de pressão.

Verificação da temperatura e pressāo alcançadas pelas pánela: de pressão

Inicialmente procurou-se pesquisar a pressisio : a correspondente temperatura alcançadas pelas panelas de pres são. Para isto foram realizadas investigaçōes junto ao setor de pesquisas e ensaios das indústrias fabricantes das panelas de pres são mais utilizadas entre nós. 
Constatou-se que as panelas de pressão mais uti lizadas alcançam pressāo e temperatura extremamente elevadas (capacidade máxima, em média de 25-28 lb/pol 2 de pressão= 130,4 - 132,99C de t.).

Quando a válvula de escape começa a funcionar, a pressão interna do aparelho já está entre 11 a $13 \mathrm{lb} / \mathrm{pol}^{2}$ ( t $=$ $116,39$ a $1199 \mathrm{C})$. E o momento em que começa a sair um jato in termitente de ar misturado com vapor dágua. Logo a seguir, a pressão se eleva ràpidamente e o jato de vapor passa a ser contí nuo. A pressão média, a partir dêsse momento, varia de 14,5 $1 \mathrm{~b} / \mathrm{pol}^{2}\left(\mathrm{t}_{0}=120,4 \mathrm{OC}\right)$ até $18 \mathrm{lb} / \mathrm{pol}^{2}\left(\mathrm{t}_{0}=124 \mathrm{\circ} \mathrm{C}\right)$ dependendo da intensidade do aquecimento. Há, no entanto, diferenças entre as várias panelas, sendo que algumas chegam a apresentar pressão média superior a $18 \mathrm{lb} / \mathrm{pol}^{2}\left(\mathrm{t}_{0}=\right.$ superior a $\left.124 \% \mathrm{C}\right)$. Estas dife renças nāo merecem maiores consideraçōes pois a menor pressão média atingida, com sua correspondente temperatura, é suficiente para a esterilizaçāo. Compreende-se esta falta de precisāo nas panelas de pressão, pois são fabricadas para fins culinários e não de esterilização.

Os dados anteriores foram colhidos em quatro indústrias. Em uma delas assistimos ao teste de determinação da relação pressão-temperatura das panelas.

Determinaçāo do processo a ser adotado para a esterilização na panela de pressāo

Confirmada objetivamente a possibilidade do uso da panela de pressão como autoclave, precisava-se determi nar o processo a ser adotado. Foram realizadas experiências uti lizando-se panelas de 3, 4 e $41 / 2$ litros de capacidade.

Inicialmente procedeu-se à improvisação do sú porte para a colocação do material a esterilizar. Êste deveria apresentar as seguintes características:

- permitir a circulação do vapor;

- permitir a correta colocaçāo dos pacotes; 
- permitir a colocação de quantidade de água necessária pa ra produzir o vapor durante a esterilizaçāo;

- ser durável e resistente;

- ser de fácil improvisaçāo

- ser de material que não umideça os pacotes.

Na primeira experiência foi utilizado suporte de varetas de madeira formando uma tela de $14 \times 14 \mathrm{~cm}$., apoiado em 4 pés de $6,5 \mathrm{~cm}$. de altura. O resultado com êste material não foi satisfatório; os pacotes permaneciam úmidos mesmo após o es friamento da panela, por absorção de água à superfície do suporte.

Nas experiências seguintes os dispositivos usa dos foram:

- lata de $17,5 \mathrm{~cm}$. de diâmetro e $6 \mathrm{~cm}$. de altura com o fundo totalmente perfurado com orifícios de $0,5 \mathrm{~cm}$. de diâmetro. Esta lata é colocada emborcada no interior da panela (foto 1-a, Anexo 1).

- lata de $18 \mathrm{~cm}$, de diâmetro, cortada em forma dentilhada à altura de $6 \mathrm{~cm}$. a partir da bôca. Sobre as bordas lisas da lata (bốca) colocou-se a grelha da panela de pressão (foto 1-b, Anexo 1).

- tela de metal (de peneira de rêdes grossas) colocada sôbre o suporte citado no ítem anterior; êstes suportes apresen taram resultados satisfatórios. Atendiam às característi cas exigidas de:

- orifícios para a circulação do vapor;

- tamanho adequado às panelas utilizadas nas experiencias;

- altura suficiente para a colocação de $1.500 \mathrm{ml}$. de água dei xando ainda um espaço de $3 \mathrm{~cm}$., vasio, no interior da pane la;

- certa durabilidade e resistência, por serem de lata;

- facilidade de confeç̧ão;

- facilidade em serem encontrados no domicílio;

- secagem total após o esfriamento da panela. 
As experiências seguintes visavam determinar:

- a quantidade de água suficiente para manter a produrgão do vapor durante o tempo requerido para a esterijização (período de exposiçāo), sem que houvesse evaporaçän to tal, sobrando, no mínimo, 50 a $100 \mathrm{ml}$. Para issu havis necessidade de se medir a quantidade de água colocáda ne panela e a quantidade restante após o esfriamento;

- tempo total gasto para o processo; para ser práiica, a esterilizaçāo na panela de pressão precisaria ser um pró cesso relativamente rápido; para determinaçāo do tiempó gasto havia necessidade de se observar; o tempo gasto s partir do início do aquecimento até o início da saída do va por intermitente; o tempo gasto a partir do início dia saj́ da do vapor intermitente até a obtençāo do vapor cuntínuc: tempo necessário para a esterilizaçāo (a partir da obte:i ção do vapor contínuo); tempo necessário para o isfrì. mento. Êste dado iría, posteriormente, orientar a deier: minação do tempo de secagem do material;

- intensidade do fogo; a intensidade do fogo é a responsá vel pela manutenção da pressāo e temperatúra da panela: em função disto procurou-se determinar a maneira de co mo regular o aquecimento; os testes demonstraram que: ao iniciar-se a eliminação do jato contínuo de vapor, deve ser diminuída a intensidade do fogo a ponto de simerite manter uniforme o referido jato.

No quadro no 2 apresentamos os resultados dos testes de verificaçāo do comportamento físico das panelas de pre E são. 
Quadro n: 2

VERIFICAÇĀO DO COMPORTAMENTO FISICO DAS PANELAS DE PRESSÃO - TESTES

\begin{tabular}{|c|c|c|c|c|c|c|c|}
\hline \multirow{2}{*}{$\begin{array}{l}\text { Capaci } \\
\text { dade da } \\
\text { panela } \\
\text { em } 1 .\end{array}$} & \multicolumn{2}{|c|}{ Quant. de água } & \multicolumn{5}{|c|}{ Tempo em minutos } \\
\hline & $\begin{array}{c}\text { Inicial } \\
(\mathrm{ml})\end{array}$ & $\begin{array}{c}\text { Final } \\
\text { (ml) }\end{array}$ & $\begin{array}{l}\text { Saída } \\
\text { do va } \\
\text { por in } \\
\text { termi } \\
\text { tente }{ }^{-*}\end{array}$ & $\begin{array}{c}\text { Obtenção } \\
\text { do vapor } \\
\text { contínuo ** }\end{array}$ & $\begin{array}{c}\text { Esterili } \\
\text { zaçāo }\end{array}$ & $\begin{array}{l}\text { Esfria } \\
\text { mentō }\end{array}$ & $\begin{array}{l}\text { Total } \\
\text { gast: }\end{array}$ \\
\hline 3 & 1000 & 600 & 7 & 7 & 15 & 10 & 39 \\
\hline 3 & 1000 & 400 & 7 & 7 & 30 & 10 & 54 \\
\hline 3 & 600 & 255 & 5 & 10 & 30 & 10 & 55 \\
\hline 3 & 600 & 310 & 7 & 7 & 30 & 10 & 54 \\
\hline 3 & 500 & 110 & 5 & 7 & 30 & 15 & 57 \\
\hline 3 & 500 & 200 & 5 & 5 & 30 & 15 & 55 \\
\hline 3 & 500 & 180 & 5 & 5 & 15 & 10 & 35 \\
\hline 3 & 500 & 200 & 5 & 5 & 15 & 10 & 35 \\
\hline 3 & 500 & 300 & 5 & 5 & 15 & 10 & 35 \\
\hline 4 & 1500 & 500 & 8 & 8 & 30 & 15 & 61 \\
\hline 4 & 1000 & 500 & 7 & 7 & 30 & 15 & 59 \\
\hline 4 & 1000 & 500 & 7 & 7 & 30 & 10 & 54 \\
\hline 4 & 600 & 210 & 7 & 7 & 15 & 10 & 39 \\
\hline 4 & 500 & 220 & 6 & 7 & 15 & 10 & 38 \\
\hline 4 & 500 & 100 & 7 & 7 & 35 & 10 & 59 \\
\hline 4 & 500 & 50 & 7 & 7 & 45 & 10 & 89 \\
\hline 4 & 500 & 50 & 7 & 7 & 45 & 10 & 69 \\
\hline $41 / 2$ & 1900 & 1000 & 8 & 8 & 20 & 15 & 51 \\
\hline $41 / 2$ & 1000 & 550 & 7 & 7 & 20 & 15 & 49 \\
\hline $41 / 2$ & 1000 & 400 & 7 & 7 & 30 & 10 & 54 \\
\hline
\end{tabular}

* Min. após o início do aquecimento.

** Min. após o início do vapor intermitente. 
A análise dos dados obtidos demonstrou que:

- a quantidade de $500 \mathrm{ml}$ de água é provàvelmente a ideal pa ra a esterilização, nas condiçōes em que se realizaram es sas experiências; com esta quantidade de água pode-se manter a produção do vapor contínuo por um período de ex posição de mais de 30 minutos, restando ainda razoável quantidade após o esfriamento da panela;

- o tempo total gasto no processo é relativamente curto co mo salientamos no quadro no 3 .

Quadro n? 3

TEMPO TOTAL GASTO NA ESTERILIZAÇĀO NA PANELA DE PRESSÃO

\begin{tabular}{c|c|c|r}
\hline $\begin{array}{c}\text { Períodc de } \\
\text { exposição } \\
\text { (min.) }\end{array}$ & $\begin{array}{c}\text { Total gasto } \\
\text { (min.) }\end{array}$ & $\begin{array}{c}\text { Período de } \\
\text { exposiçáo } \\
\text { (min.) }\end{array}$ & $\begin{array}{r}\text { Total gasto } \\
\text { (min.) }\end{array}$ \\
\hline 15 & $35-39$ & 30 & $54-61$ \\
20 & $49-51$ & 35 & 59 \\
& 45 & 69 \\
\hline
\end{tabular}

O vapor intermitente começa a ser eliminado de 5 a 8 minutos após o início do aquecimento e o vapor contínuo é ob tido após 5 a 10 minutos do início da eliminaçāo do vapor intermi tente (o vapor contínuo é identificado pelo jato contínuo de vapor que se visualiza contra a luz, como se fôsse um feixe esbranquiça do). Eimportante a identificação do vapor contínuo, pois, sòmen te com a sua obtenção é que se deve começar a contagem do perío do de exposição, que varia de acôrdo com o material a esterilizar.

O esfriamento ocorre de 10 a 15 minutos após término do período de exposição, isto $\dot{e}$, no momento em que se apaga o fogo. Êste dado é de grande importância por correspon der ao tempo de secagem do material. O esfriamento deve ser 
realizado com a panela fechada, deixada sôbre uma superfície nāo muito fria, para evitar a condensaçāo do vapor e o consequente umidecimento dos pacotes.

Houve variaçōes de relativa significância no tem po gasto para a obtenção do vapor intermitente e contínuo, assim como na quantidade de água restante. Estas variaçōes são essen cialmente devidas à fonte de aquecimento, pois, nessas experiên cias foi utilizado o gás de rua, que apresenta grandes oscilaçōes na intensidade do fluxo.

Como vimos, os dados obtidos confirmaram a praticidade do processo.

Para completar a determinação do processo a ser adotado na autoclavagem em panela de pressāo, restava-nos apenas saber quais as condiçōes em que saíam os pacotes após a fase de esfriamento.

Foram feitos testes utilizando material de densi dade (gaze) e de superfície (seringas e agulhas), ambos acondicio nados em campos de algodãozinho cru de $35 \times 35 \mathrm{~cm}$. (pacotes de $13 \times 8 \times 3 \mathrm{~cm}$, aproximadamente) e em papel manilha de $30 \times 30$ cm. (pacotes de $11 \times 7 \times 2 \mathrm{~cm}$. aproximadamente). Êstes pacotes foram colocados em panelas de 3, 4 e 4 1/2 litros de capacidade, sobre os suportes já descritos anteriormente. Os suportes com portavam de 4 a 5 pacotes de maior tamanho e cie 7 a 10 dos meno res, dependendo da variação individual do volume do pacote.

No preparo e na colocação dos pacotes foram aplicados os mesmos princípios da esterilização em autoclave ver tical: : aproveitar apenas $85 \%$ da capacidade da panela, pacotes acondicionados em material permeável ao vapor e dispostos deita dos oblìquamente sobre um dos lados de modo a facilitar a circula ção do vapor. (fotos 2, 3, 4, Anexo 2).

O material de superfície foi exposto durante 15 minutos ao vapor contínuo e o de densidade durante 30 minutos.

Esperávamos que o tempo de esfriamento da pa nela (panela fechada, colocada sobre uma superfície não muito fria 
até o desaparecimento da pressão interna) correspondesse ao tem po de secagem do material. Quando a panela estivesse totaimen te sem pressão interna o material deveria estar sêco.

As primeiras experiências demonstraram, no en tanto, que tal fato não ocorria; os pacotes saíam úmidos arós a fase de esfriamento.

Tentou-se saber então, que fatôres estariam it: fluindo nas condições de secagem do material ao saírem da parielia.

Levantamos a hipótese de que fôsse 0 modo de secagem, pois era pouco provável que a quantidade de água ưiiiza da estivesse influindo, uma vez que a quantidade provável ideả pr. ra a esterilização já havia sido fixada em $500 \mathrm{ml}$.

Fizeram-se entāo experiências com modifica çōes na secagem, com um período de secagem fechada seguido de um período de secagem aberta (com uma abertura mínima na tan: pa).

Os resultados dessas experiências estão aprạ sentados nos quadros no 4 e no 5 .

\section{Quadro n? 4}

ESTUDO DAS CONDIÇŌES DE SECAGEM - MATERIAL DE DEN SIDADE (30 minutos de período de exposição)

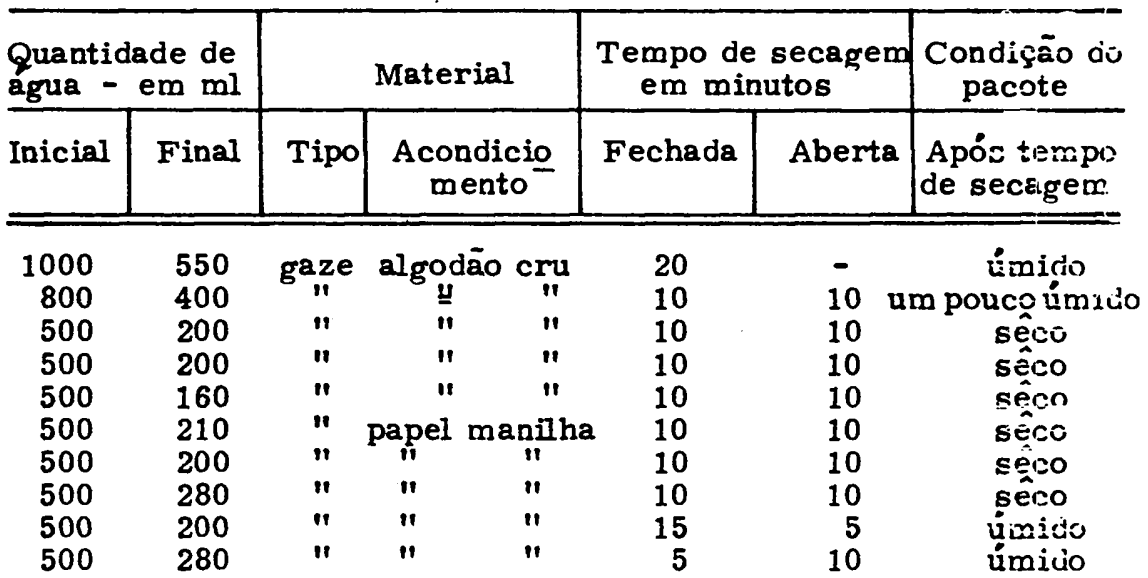


Analisados os dados obtidos, foi observado yue, com a secagem fechada, mesmo por um período de tempo de 15 a 20 minutos, os pacotes saem úmidos e que sòmente saem sêcos quando se empregam 10 minutos de secagem fechada, seguidos de 10 minutos de secagem aberta.

Quadro no 5

ESTUDO DAS CONDIÇÕES DE SECAGEM DOS PACOTES - MA TERIAL DE SUPERFICIE (período de exposição - 15 minutos)

\begin{tabular}{|c|c|c|c|c|c|c|c|}
\hline \multicolumn{2}{|c|}{$\begin{array}{l}\text { Quantidade de } \\
\text { aggua - em ml }\end{array}$} & \multicolumn{3}{|c|}{ Material } & \multicolumn{2}{|c|}{$\begin{array}{c}\text { Tempo de seca } \\
\text { gem em minu } \\
\text { tos }\end{array}$} & \multirow{2}{*}{$\begin{array}{l}\text { Cordiçãr } \\
\text { do pacot:- } \\
\text { Apćs tem } \\
\text { po de sie } \\
\text { cagem }\end{array}$} \\
\hline Inicial & Final & Tipo & $\begin{array}{c}\text { Acondici } \\
\text { nament }\end{array}$ & & Fechada & Aberta & \\
\hline 800 & 350 & $\begin{array}{l}\text { agulha em } \\
\text { tubo de ens. }\end{array}$ & $\begin{array}{l}6 \text { tubos e } \\
\text { godáo c }\end{array}$ & eru al & 20 & - & timids \\
\hline 600 & 200 & " & 11 & $"$ & 20 & - & ámido \\
\hline 500 & 110 & $"$ & $"$ & $"$ & 20 & - & úmido \\
\hline 500 & 130 & $"$ & $"$ & $"$ & 15 & 5 & úmido \\
\hline 500 & 200 & $"$ & $"$ & $"$ & 5 & 15 & úmido \\
\hline 500 & 100 & $"$ & $"$ & $"$ & 10 & 10 & sêeco \\
\hline 500 & 110 & $"$ & $"$ & $"$ & 10 & 10 & sërco \\
\hline 500 & 100 & $"$ & $"$ & $"$ & 10 & 10 & ssêco \\
\hline 500 & 150 & $"$ & $\begin{array}{l}6 \text { tubos e } \\
\text { pel manil }\end{array}$ & em pa & 10 & 5 & úmido \\
\hline 500 & 200 & $"$ & " & & 10 & 10 & ssêco \\
\hline 500 & 180 & 11 & $"$ & & 5 & 10 & ímido \\
\hline 500 & 200 & seringas & papel ma & anilha & 15 & 5 & úmido \\
\hline 500 & 100 & $"$ & " & $"$ & 10 & 10 & sêco \\
\hline 500 & 100 & $"$ & $"$ & $" 1$ & 10 & 10 & $E \hat{E} \bar{i} 0$ \\
\hline 500 & 300 & $"$ & algodão & cru & 10 & 10 & s.êco \\
\hline 500 & 200 & $"$ & $"$ & $"$ & 10 & 10 & sêeco \\
\hline 500 & 180 & $"$ & $" 1$ & $"$ & 10 & 5 & úmido \\
\hline 500 & 100 & $"$ & $"$ & $"$ & 10 & 10 & sêco \\
\hline
\end{tabular}


As experiências confirmaram que existe real mente uma quantidade ideal de água necessária à esterilização e esta quantidade deve ser a que possa prover o vapor durante o pro cesso sem deixar úmidos os pacotes após o período de secagem. Nas condiçōes em que foram realizadas essas experiências, a quantidade ideal foi de $500 \mathrm{ml}$.

Com êstes resultados foi possível estabelecer o processo a ser adotado na esterilização em panela de pressão, des crito a seguir:

- colocar quantidade de água que permita o fornecimento de va por durante o processo, sem no entanto umidecer os pacotes; nas condiçōes em que foram afetuadas as experiências, para as panelas de 3,4 e 4 1/2 litros de capacidade, esta quantida de é de $500 \mathrm{ml}$;

- colocar o suporte no interior da panela deixando um espaço de no mínimo $3 \mathrm{~cm}$. entre a água e a superfície do suporte; para as panelas da capacidade acima citada a altura ideal do suporte é de $6 \mathrm{~cm} . ;$ êste suporte deve ser de material que não umideça os pacotes;

- colocar o material sobre o suporte, dispondo-o de modo a fa cilitar a circulaçāo do vapor;

- fechar a panela, colocar a válvula e iniciar o aquecimento com a máxima intensidade do fogo;

- esperar até se conseguir o vapor contínuo (jato contínuo de vapor que se visualiza contra a luz como um feixe esbranqui çado);

- obtido o vapor contínuo, diminuir a intensidade do fogo a pon to de sòmente manter uniforme aquêle jato de vapor;

- iniciar, a partir dêste instante, a contagem do período de ex posição;

- após o término do período de exposiçāo, apagar o fogo e dei xar a panela de fogão ou em superfície nāo muito fria, com a tampa fechada durante 10 minutos (secagem fechada); 
- proceder à secagem aberta, durante 10 minutos, isto é, com a tampa sobre a panela, deixando aberta uma pequena fresta;

- retirar os pacotes e colocá-los sôbre uma superfície sêca e nāo muito fria;

- guardá-los em local séco e protegido, após o esfriamento to tal*.

Testes de eficiência da esterilização na panela de pressão

Estabelecido o processo de esterilizaçāo em pa nelas de pressão, era necessário verificar sua eficiência. Isto foi realizado através de 3 séries de novas experiências, em que o pro cesso determinado foi aplicado concomitantemente a testes de efi ciêncir. Assim, para verificar a eficiéncia da autoclavagem do material de densidade, foi utilizado o teste biológico já descrito anteriormente. Para o material de superfície a verificação con sistiu em contaminar o próprio material e, após confirmar esta contaminaçāo, submetê-lo à autoclavagem na panela de pressão e depois à cultura.

A 1 a série dessas experiencias foi realizada em 1964; a $2^{a}$ e a 3 a em março e maio de 1970, respectivamente.

A autoclavagem foi feita no laboratório de Bio química da Escola de Enfermagem da USP e os testes microbioló gicos no labcratório do Departamento de Microbiologia e Imunolo gia da Faculdade de Medicina da USP, com Dra. Cecillia Mattos Ulson, e no laboratório de Bacteriologia do Hospital das Clínicas da Faculdade de Medicina da USP.

Em tôdas as experiências procurou-se manter constante a quantidade de pacotes a esterilizar. Esta quantidade foi de 4 pacotes de material acondicionado em campo duplo de al godāozinho cru e 6 de papel manilha.

* Esta orientação é destinada às panelas de 3,4 e 4 1/2 litros de capacidade, utilizadas nas condiçóes idênticas às observadas nes sas experiencias. Para as panelas diferentes, deverão ser fe tas adaptaçōes. 
Verificação da eficiência da panela de pressão na esterilização do material de densidade.

Utilizou-se como contróle, em cadà uma das ex periências, um cadarço contaminado com esporos do Bacilius sub tilis, de contaminaçāo prèviamente comprovada. Êste cacara̧̧o foi envolvido em gaze e acondicionado em campo dupio de algodän cru (35 $355 \mathrm{~cm}$.). Colocou-se o pacote assim feito sôbre o suporte da panela, (fotografia no 5, Anexo 3), no centro dos demais nacote; e procedeu-se à autoclavagem. Terminada esta, o cadarço foi zse meado obedecendo às normas da técnica assética em meic je Thio gliconato e incubado a 37 . C.

Foram realizadas 3 séries de 16 experiêncis: em que se autoclavaram pacotes de gazes e bolas de algodãu, utij zando-se a seguinte identificação:

Cadarço de contrôle Identificaçāo

$A 1, A 2, A 3, A 4$

- colocado no centro de 4 pacotes de cam. po duplo de algodão cru $(35 \times 35)$, contein do 10 gazes;

$\mathrm{B} 1, \mathrm{~B} 2, \mathrm{~B} 3, \mathrm{~B} 4$

$\mathrm{C} 1, \mathrm{C} 2, \mathrm{C} 3, \mathrm{C} 4$

- idem, idem, contendo 10 bolas de alge dão;

- colocado no centro de 6 pacotes de pape: manilha, contendo 10 gazes;

D1, D2, D3, D4

- idem, idem, contendo 10 bolas de algrcião;

$\mathrm{Y}$

- amostra dos cadarços contaminaduss utiit zada para prova de contaminação iseme: da em Thioglicolato).

Os resultados experimentais aparecem $20 \mathrm{Q}$ dro n: 6 juntamente com os respectivos resultados do teste mi crobiológico realizado em Thioglicolato. 
Quadro no 6

TESTES DE EFICIÊNCIA DA ESTERILIZAÇÃO DO MATERIAL DE DENSIDADE EM PANELA DE PRESSĀO

\begin{tabular}{|c|c|c|c|c|}
\hline \multirow[t]{2}{*}{ Cadarço } & \multirow[t]{2}{*}{$\begin{array}{c}\text { Período de } \\
\text { exposição } \\
\text { (em min.) }\end{array}$} & \multicolumn{3}{|c|}{$\begin{array}{l}\text { Resuitado da cultura em Thioglisolato, } \\
\text { após } 8 \text { dias de incubaçāo }\end{array}$} \\
\hline & & Novembro-1970 & Março-1970* & Maic-197ú \\
\hline $\mathrm{A} 1, \mathrm{~B} 1, \mathrm{C1}, \mathrm{D} 1$ & 10 & + & + & 4 \\
\hline $\mathrm{A} 2, \mathrm{~B} 2, \mathrm{C} 2, \mathrm{D} 2$ & 28 & - & - & - \\
\hline $\mathrm{A3}, \mathrm{B3}, \mathrm{C} 3, \mathrm{D} 3$ & 25 & - & - & - \\
\hline $\mathrm{A} 4, \mathrm{~B} 4, \mathrm{C} 4, \mathrm{D} 4$ & 30 & - & - & - \\
\hline $\mathrm{Y}$ & - & + & + & + \\
\hline
\end{tabular}

* Após 3 dias de incubação.

Verifica-se que o resultado da cultura foi negat; vo para os cadarços autoclavados durante 20,25 e 30 minutcs, $c$ positivo para os autoclavados durante 10 minutos. Êstes resüt dos demonstram que o cadarço contaminado com esporos do B. sui tilis são esterilizados na panela de pressão em um período de ex posição de 20 minutos. Consequentemente, podemos afirmãr que aquêle utensílio doméstico é realmente uma pequena autoclave, exi que 30 minutos de exposiçāo para a esterilização do material de densidade são mais do que suficientes.

Verificação da eficiência da panela de pressāo na esterilizaçāo do material de superfície.

Realizaram-se testes utilizando diversos tipos de material: agulhas de injeçāo, pinças de sobrancelha, pedaços de arame de 3 -cm., de comprimento e tubos intermediários ce vi dro de $4 \mathrm{~cm}$. de comprimento.

O material foi contaminado com esporos do $B$. subtilis e uma amostra semeada em Thioglicolato para se verifi car a viabilidade do esporo. Após resultado positivo dessa prova de contaminação, o material foi autoclavacio em pacotes de aiģo 
dão cru e de papel manilha. Após o término da autoclavagem pro cedeu-se à cultura semeando o próprio material no meio de Thio glicolato, com a conveniente identificação.

$\underline{\text { Identificaçāo }}$

Material

E1, E2, E3, E4 - 3 agulhas prêsas em uma gaze, acondicionadas em campo duplo de algodão cru;

F1, F2, F3, F4 - idem, idem, acondicionadas em papel manilha;

G1, G2, G3, G4 - 6 agulhas em tubos de ensaio, acondicionados em caropo de algodão cru;

H1, H2, H3, H4 - idem, idem, em papel manilha;

$m, n, o, p$ - amostra para teste de cortaminação (para verifi cação da viabilidade do esporo utilizado), respeç tivamente de $\mathrm{E}, \mathrm{F}, \mathrm{G}$ e $\mathrm{H}$.

E possível esterilizar material de superfície em 15 minutos e material de densidade em 30 minutos, adotando-se o processo descrito neste trabalho. Eum processo eficiente, fácil, prático, económico e acessível à população de modo geral e às pe quenas instituiçōes de saúde. O tempo total gasto é relativamen te curto, sendo de 35 a 39 minutos para o material de superfície e de 54 a 69 minutos para o de densidade. A quantidade de pacotes esterilizados em cada operação é relativamente grande (as panelas de 3,4 e 4 1/2 litros de capacidade comportam de 4 a 5 pacotes de aproximadamente $13 \times 8 \times 3 \mathrm{~cm}$. e de 7 a 10 litros de $11 \times 7 \times 2 \mathrm{~cm}$.).

Seu uso é perfeitaraente viável, não só nas farmá cias, consultórios médicos ou dentários, centros ou postos de saú de, mas também no domicílio, mesmo na zona rural.

RECOMENDAÇÕES

Considerando as conclusōes obtidas recomenda mos: 
- a utilização da panela de pressão como autoclave para esteri lizar seringas, agulhas, ataduras, gazes, bolas de algodão, pinças e cadarços para curativos, mamadeiras e qualquer ou tro material que possa ser esterilizado com vapor d'água sob pressão;

- a substituição da fervura de material (que apenas desinfeta) por êste método, em farmácias, consultórios médicos ou den tários, postos e centros de saúde, ambulatórios, assim como no domicílio;

- a divulgação dêste processo pois é um recurso comprovada mente eficiente de esterilização.

\section{SUMÅRIO}

Confirmação da possibilidade da utilização da pa nela de pressão como autoclave e estabelecimento do processo a ser adotado para êsse fim. Pesquisa nas fábricas de panelas de pressão constatou que a pressão média atingida é de $14,5 \mathrm{lb} / \mathrm{pol}^{2}$ $(t .=120,49 \mathrm{C})$ a $18 \mathrm{lb} / \mathrm{pol}^{2}(\mathrm{t} .=124 \mathrm{o} \mathrm{C})$. Improvisaçōes de su porte para colocação do material adaptam a panela para esteriliza ção. Experiências na autoclavagem do material de superfície e de densidade em panelas de 3, 4 e 4 1/2 litros de capacidade possi bilitaram o estabelecimento do processo de esterilização pela pa nela de pressão. Testes microbiológicos verificaram a eficiên cia do processo confirmando que a panela de pressāo doméstica pode ser utilizada como autoclave. A esterilização de material de superfície é obtida em 15 minutos e o de densidade em $30 \mathrm{minu}$ tos. O processo é fácil, prático, econômico e acessível a todos. 


\section{Quadro no 7}

TESTES DE EFICIÊNCIA DA ESTERILIZAÇÃO DO MATERIAL DE SUPERFÍCIE EM PANELA DE PRESSÃO

\begin{tabular}{l|c|c|c|c}
\hline & $\begin{array}{c}\text { Período de } \\
\text { exposição } \\
\text { (em min.) }\end{array}$ & $\begin{array}{r}\text { Resultado da cultura em Thiogliconato, } \\
\text { após 8 dias de incubação }\end{array}$ \\
\cline { 3 - 5 } & & Novembro-1964 & Março-1970* & Maio-1 970 \\
\hline \hline E1, F1, G1, H1 & 13 & - & - & - \\
E2, F2, G2, H2 & 13 & - & - & - \\
E3, F3, G3, H3 & 15 & - & - & - \\
E4, F4, G4, H4 & 15 & - & + & + \\
m, n, o, p & - & + & & - \\
\hline
\end{tabular}

* Após 3 dias de incubação

Os resultados demonstram que o materia' de su perfície é esterilizado na panela de pressão em 13 minutos. Par̀a maior segurança é aconselhável que se autoclave durante $15 \mathrm{minu}$ tos.

Foram ainda realizados alguns ensaios da mes ma natureza, utilizando-se pinças de sobrancelhas, pedaços de arame de $3 \mathrm{~cm}$. , e tubos intermediários de vidro. Os resultados foram idênticos aos apresentados no quadro acima.

\section{CONCLUSŌES}

A panela de pressão doméstica pode ser utiliza da como autoclave. Atinge pressão e correspondente temperatura extremamente elevadas (pressão máxima:- 25 a $28 \mathrm{lb} / \mathrm{pol}^{2}$, tempe ratura:- 130,4 a $132,9 \circ \mathrm{C})$.

A pressão média mantida a partir da obtenção do vapor contínuo é de $14,5 \mathrm{lb} / \mathrm{pol}^{2}\left(\mathrm{t}\right.$. $=120,4 \mathrm{ọ}$ ) até $18 \mathrm{lb} / \mathrm{pol}^{2}$ $(\mathrm{t} .=124 \mathrm{C})$, dependendo essencialmente da intensidade do fogo. Existem variaçōes que não merecem maiores considerações, pois, com a maior pressão média e correspondente temperatura pode mos assegurar a esterilização. 


\section{ANEXO 1}

Fotografia 1
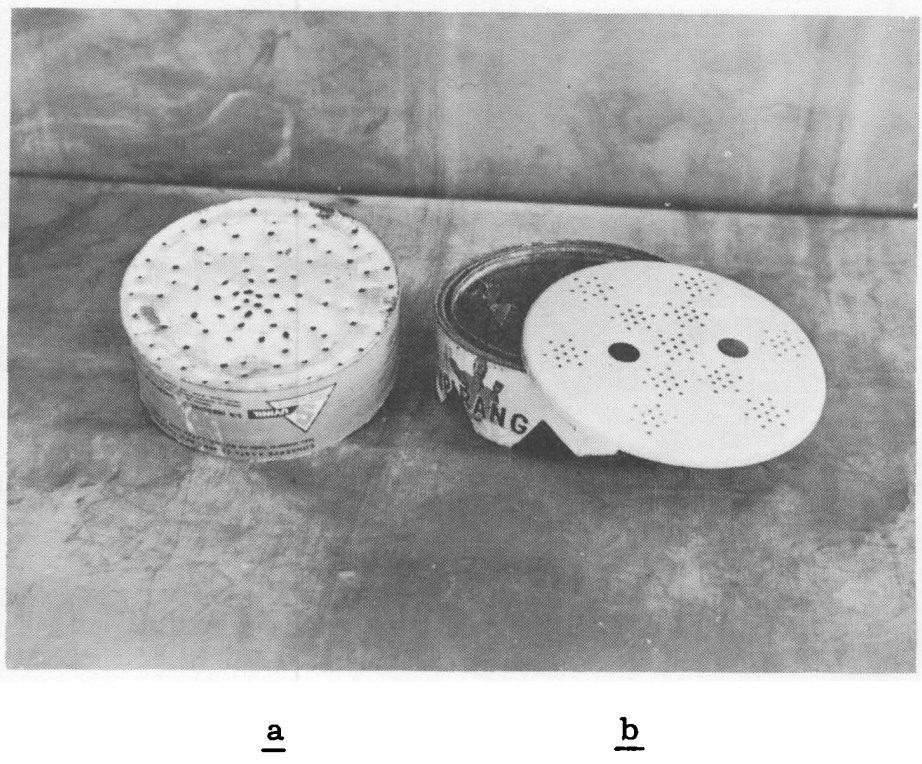

ANEXO 2

Fotografia 2

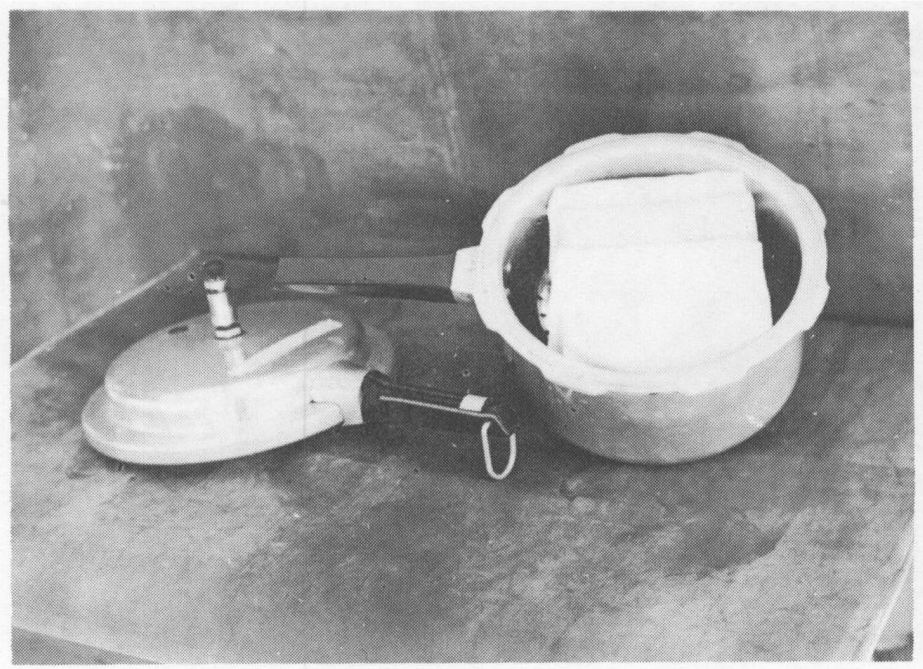


$-76-$

Fotografia 3

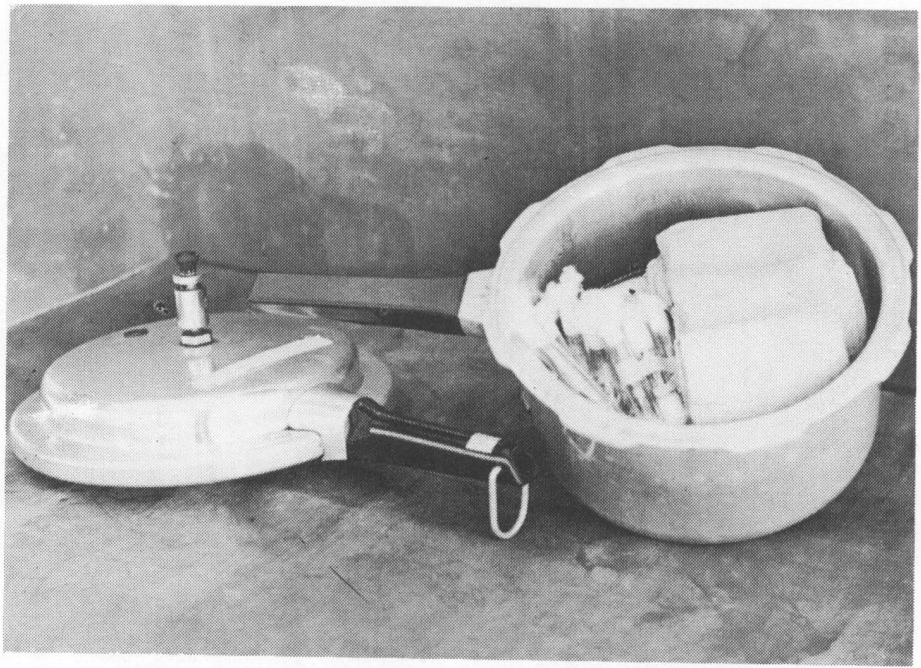

Fotografia 4

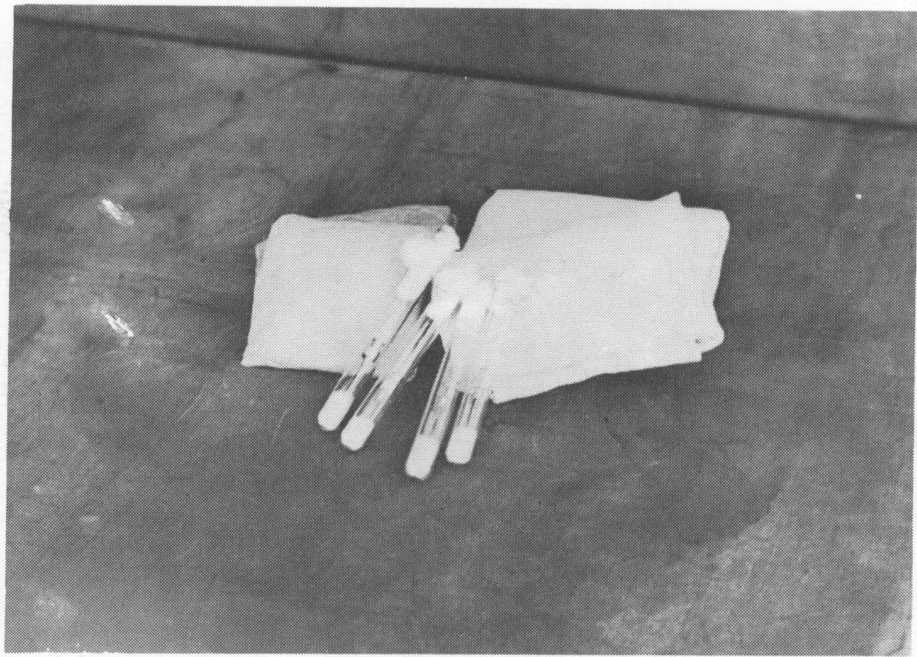


ANEXO 3

Fotografia 5

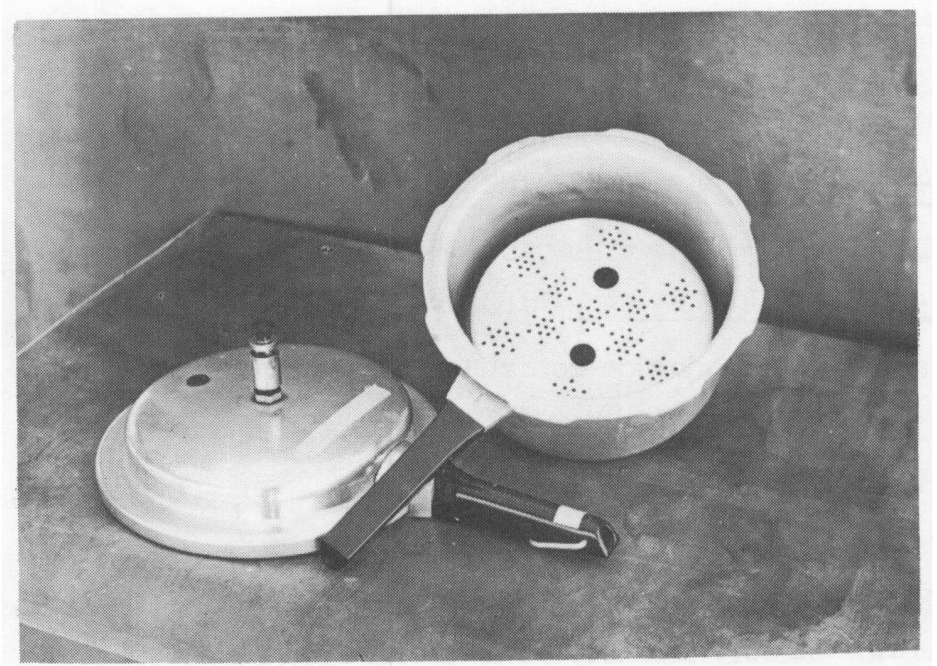


REFERÊNCIAS BIBLIOGRÅFICAS

BIER, O. - Bacteriologia e imunologia. 13ą ed. Melhoramentes, 1966.

BOLETIM Epidemiológico, 1, 1968.

BRASIL. INSTITUTO BRASILEIRO DE GEOGRAFIA E ESTA'TSSTI $\mathrm{CA}$ - Anuário estatístico do Brasil, 1968. Rio de Janeirc, IBGE, 1968.

BRASIL. INSTITUTO BRASILEIRO DE GEOGRAFIA E ESTÁTISTI CA - Anuário estatístico do Brasil, 1969. Rio de Janeiro, IBGE, 1969.

CARVALHO, R.S. - Desenvolvimento do conceito de assepsis. Hospital de Hoje, 15: 37, 1962.

CRISTOVĀO, D. - Esterilizaçāo do material hospitalar. Esevisista Paulista de Hospitais, $\underline{4}$ (8): 15-31, ago., 1956.

DANTAS, P. - Métodos de esterilização. Revista Paulista díllos pitais, 9 (2): 27-30, fev., 1961.

FROBISHER, M. - Microbiologia médica. 3a ed. Barcelona, Sa? vat, $[1964]$.

FROBISHER, M. [y otros] - Microbiologia y patologia para enfer meras. 5a ed. México, Interamericana, 1960.

LIMA, L.P.C. - Métodos físicos de desinfecçāo e esterilizuçāo. Hospital de Hoje, 16: 29, 1962.

PELCZAR, M.J. (Jr.) [and] REID, R.D. - Microbiology. London, McGraw-Hill, 1958.

PERKINS, J.J. - Principles and methods of sterilization. $2^{\text {nd }}$. eci. Springfield, Charles C. Thomas, [1969].

RICHTER, E.B. - Aulas de enfermagem em centro cirúrgico: pos tila. São Paulo, Escola de Enfermagem da USP, s.d.

SILVA, R.B. - Termodinâmica, transmissāo de calor e máq̨uinas térmicas: postila. Sāo Paulo, Escola Politécnica da USP, 1963. 
STANIER, R. [e outros] - O mundo dos micróbios. São Paulo, Ed. da USP, 1969.

VERONESI, R. [e outros] - Doenças infecciosas e parasitárias. 4a ed. Rio de Janeiro, Guanabara-Koogan, 1969.

WITTON, C.J. - Microbiologia. México, Continental, 1964.

KAMIYAMA, Y. - Experiências sôbre a utilidade da panela de pressão como autoclave. Rev. da Esc. de Enf. da USP, $\underline{4}(1-2): 55-79$, marset., 1970 . 